\title{
"What is a Sociologist Doing Here?" An Unconventional People-Centered Approach to Improve Warning Implementation in the Sendai Framework for Disaster Risk Reduction
}

\author{
Victor Marchezini ${ }^{1,2,3}$
}

Published online: 15 April 2020

(C) The Author(s) 2020

\begin{abstract}
The Sendai Framework for Disaster Risk Reduction 2015-2030 recommends several actions for early warning systems (EWSs). However, there is a lack of information about their means of implementation. This article used institutional ethnography to analyze the 2012-2018 implementation of a national warning system in Brazil. The challenges related to daily activities, and the interdisciplinary works in the four axes of EWSs towards multi-hazard and people-centered approaches are discussed. This national experience is then discussed in the light of the global challenges of EWSs considering two main issues: (1) experiences of implementation and barriers related to people-centered warning systems; and (2) types of national/regional warning systems and hazards/ threats that are being monitored as an important input for multi-hazard approaches. There are few multi-hazard warning systems in place and EWSs are focused on hydrometeorological hazards, mainly related to floods. The Sendai Framework needs to improve access to data and information, identify views from the frontline, consider political threats and vulnerabilities, and find ways to talk about disaster risk creation processes at a larger scale.
\end{abstract}

Victor Marchezini

victor.marchezini@cemaden.gov.br

1 Cemaden - National Early Warning and Monitoring Center of Natural Disasters, Distrito de Eugênio de Melo 12.247-016, São José dos Campos, SP, Brazil

2 Doctorate Program on Earth System Science, National Institute for Space Research, São José dos Campos, Brazil

3 Programa de Pós-Graduação em Desastres Naturais, ICT/ Unesp-Cemaden, São José dos Campos, Brazil
Keywords Risk governance · Interdisciplinary research $\cdot$ People-centered warning systems

\section{Introduction}

Over the past 8 years I have been working at the Brazilian National Early Warning and Monitoring Center of "Natural" Disasters, a warning agency that was created after a catastrophe in Rio de Janeiro State in 2011. My co-workers-many of them scientists from natural sciences-used to ask me: "What is a sociologist doing here?" Inspired by this interesting question and by social scientists that analyzed other scientific laboratories (Latour and Woolgar 1986), I decided to conduct an institutional ethnography (Devault 2006) of this warning agency from January 2012 to January 2018, 3 years before and after the Sendai Framework for Disaster Risk Reduction 2015-2030 (SFDRR) (UNISDR 2015). Institutional ethnography "generally takes some particular experience (and associated work processes) as a "point of entry" (Devault 2006, p. 294). It is based on the examination of work processes and how they are coordinated, taking them as the fundamental grounding of social life (Devault 2006). During this period of institutional ethnography in the warning agency, I worked in the monitoring department (2.5 years) and in the research department (3.5 years), and through empirical observation I traced social relations during the warning agency implementation.

For Devault (2006), the point of institutional ethnography is the possibility to show how people in one place are aligning their activities with relevancies produced elsewhere-such as the SFDRR recommendations-in order to illuminate the forces that shape experience. In this article I am sharing some findings regarding the implementation of 
the warning system. Moving from this national agency experience analyzed from 2012 to 2018, the second part of this article discusses some global challenges of warning systems. This analysis was based on scientific and grey literature in Spanish and in English (Basher 2006; Kelman 2006; UNISDR 2006a, 2006b; Thomalla and Larsen 2010; Zia and Wagner 2015; Dávila 2016; Macherera and Chimbari 2016a; WMO 2018). First, an overview of the challenges of people-centered early warning systems (EWSs) and multi-hazards is provided, complementing previous discussions (Garcia and Fearnley 2012; Villagrán de León et al. 2013; Grasso 2014; Kelman and Glantz 2014; Baudoin et al. 2016). Finally, pathways for the Sendai Framework are discussed.

\section{An Ethnographer in the Warning System: Challenges of Implementation}

The warning agency where I have been working and conducting participant observation was created during the aftermath of floods and debris flows that buried more than 1,000 people in January 2011 in the mountain region of Rio de Janeiro State, Brazil. The gold rush in this case happened in the ministries of the national government that immediately had to put in place several recommendations of the Hyogo Framework for Action (HFA) (UNISDR 2005): (1) landslide and flood susceptibility analysis was conducted on the ground in more than 1,000 cities, and maps-labelled as "risk" mapping-were prepared in the shapefile format by the Geological Service; (2) a weather monitoring network (radar, rain gauges, river level stations) was bought and installed in these mapped areas by the recently created warning agency; (3) partnerships with federal, state, and local agencies to exchange environmental data and information were formed; (4) computer scientists also developed a GIS visualization platform to receive these kinds of data; (5) people were hired to work in the monitoring room and to be part of the decisionmaking process in the warning chain, which also includes civil protection units at the federal, state, and municipal levels, as well as at-risk communities; (6) protocols for this warning chain were also necessary, especially because the roles and responsibilities of the organizations were not clear-the competition between governmental agencies (Lund 2006) was real; and (7) capacity building tutorials and educational materials on warning system implementation at local level were recognized as important, but there is no consensus about who is responsible for engaging people in warning system.

Many of these steps and tasks were recommended in the warning system checklists published by the United Nations International Strategy for Disaster Reduction (UNISDR 2006a) and the World Meteorological Organization (WMO 2018); some barriers for their implementation were sporadically researched using questionnaires and interviews (Lumbroso et al. 2016; Horita et al. 2017, 2018), but not the everyday practices and discourses of warning implementation during a period of time, as institutional ethnography permits. This article contributes to this debate, providing insights about the means of implementation of warning systems (Zia and Wagner 2015). This section focuses on three dimensions: daily implementation, interdisciplinary projects, and people-centered and multi-hazard approaches.

\subsection{The Daily Implementation of Warning Systems}

Many scholars have written about the complexities involving EWSs. Sorensen (2000) stated that warning systems are complex because they involve many fields of knowledge and organizations-science, government, engineering, the private sector, technology, news media, and the public. Kelman and Glantz (2014) emphasized the importance of thinking about the different social contexts where warning systems are operating. These contexts are becoming ever more complex, as are the definitions of warning systems. The most updated definition of UNISDR (2017) considers EWS as an "integrated system of hazard monitoring, forecasting and prediction, disaster risk assessment, communication and preparedness activities systems and processes that enable individuals, communities, governments, businesses and others to take timely action to reduce disaster risks in advance of hazardous events." This warning system should be composed of four subsystems: risk knowledge, monitoring, communication, and response capability. Risk knowledge is the systematic data collection and analysis of hazards/threats and vulnerabilities-physical, social, economic, environmental, and so on-that merge in risk scenarios subject to changes in the short and long terms, and across different spatial scales. Monitoring implies the resources and capacities for collecting and checking dynamic data and information on hazards/threats and vulnerabilities, to be able to take decisions on the basis of prior risk knowledge. Communication is the process of sharing data, information, and knowledge about the risks (hazards and vulnerabilities), and warning situations. Response capability is the preparedness capacity to know how to act, and is often rooted in the resources, skills, and networks that people have. Capability is not just determined by personal abilities but the freedom and access to resources (opportunities) created by the political, social, and economic structures (Wisner 2016).

Despite the inspiring message of integration, the daily routines of a warning system are not integrated. 
Unexpected priorities appear and available funding will not be equally distributed in the four axes of a warning system. Dávila (2016), in her analysis of 21 flood warning systems in Latin America and the Caribbean (LAC), reported that there are situations where monitoring tasks are being performed without the risk mappings, so the communication of warnings does not define the highly vulnerable areas exposed to hazards, and consequently undermines the contingency planning and the evacuation measures, revealing the failures in the interconnection of the four subsystems of EWSs. In my case study, investments were made to buy and maintain the sensors, but local capacity building efforts to use data and information to build and implement disaster risk management (DRM) action plans were rare. When disasters occur, public opinion demands a political response that is usually framed and funded according to the problem-solving mechanisms available to the organizations (Dombrowsky 1998). These solutions tend to be concentrated on monitoring and engineering, reinforcing the status quo and the lobbying that occurs in the field of disaster management (Hewitt 1983). During any so-called "windows of opportunity" for those well established to use them, facts and arguments are used to frame what a disaster is according to the power interests. Solutions and illusions of disaster capitalism appear (Klein 2008), promises of "build back better" bubble up and are critiqued (for example Maly and Suppasri 2020), papers are published, and survivors are left to fend for themselves in the continuity of the disaster.

Warning systems are one of the solutions sold. The funding received by EWSs is used to establish monitoring networks with sensors that measure and provide environmental data, as verified after the 2004 tsunami (Kelman 2006). Years pass and DRM is not on the political agenda anymore. Financial constraints related to the budget for the maintenance of the monitoring networks become frequent. The lack of and/or deterioration of monitoring networks is usually mentioned as one of the main barriers of warning systems, as stated by several experts working with weatherrelated hazards in Africa and the Caribbean (Lumbroso et al. 2016). The financial costs associated with the maintenance of monitoring networks also vary, as well as the economic capacity to cover their costs (Dávila 2016).

Lack of funding was reported as one of the most frequent impediments to EWSs, but other impediments are the inadequate coordination between local, national, and regional levels, and the lack of human resources and of EWS infrastructure (Grasso 2014). In Ecuador, the lack of human resources in DRM, the lack of consensus in warning terminology, the poor DRM coordination between government levels, as well as political influence were some of the challenges of the tsunami warning system (Norambuena 2011). Dávila (2016) also warned about the high rates of employee turnover, the changes in management positions, the lack of human resources at the local level, and the political influence in flood warning systems in South and Central America. She pointed out that legislation, documents, and capacity building can be important measures to reduce the influence of political parties, but this is not enough. It is important to increase transparency and give feedback about the investments in each of the four subsystems of EWSs. She added that warning technology must be used with precaution, because it can create new inequalities and/or accentuate the lack of access to information (Dávila 2016).

Lack of coordination between and across the warning system scales - national, state, city, and neighborhoods-is a governance challenge. In my case study, a survey to identify the local, state, and federal hazard monitoring agencies was carried out in 2017, 6 years after the creation of the national warning agency. The survey identified 71 monitoring agencies at the national, regional, state, and local levels. Of this sample, most local and state hazard monitoring agencies were created before the national warning agency (Marchezini, Londe, et al. 2017). Multiple diverse criteria for warning levels were identified, similar to the findings reported by the Global Survey of Early Warning Systems (UNISDR 2006b) and other studies (Villagrán de León et al. 2013).

The United Nations International Strategy for Disaster Reduction (UNISDR) checklist for warning systems (UNISDR 2006a) states that effective governance is supported by legal and regulatory frameworks, as well as by the long-term political commitment that demands vertical and horizontal communication. In 2017, we organized a three-day national seminar for warning system practitioners to receive feedback-from municipal and state civil protections - about the performance of the national warning agency services. The main topics of discussion were monitoring networks, information, and the challenges of involving people in the municipal warning system. Federal agency representatives working in DRM were invited to participate in a roundtable where each of them explained the roles of their agencies in the National Plan for DRM (Marchezini, Londe, et al. 2017; Saito et al. 2019). This was important because the National Plan for DRM was created in the aftermath of the 2011 catastrophe, but the written plan is not available on the internet. The national seminar also had a slot for municipal civil units that wanted to share their practices and the challenges of implementing warning systems. This was very interesting because many municipal civil units are monitoring hazards but they have not received capacity building activities from state or national warning agencies to learn how to design a warning system. It is important to highlight that no representatives of communities affected by disasters were invited by the 
seminar's organizing committee to participate in the 2017 national seminar. How do warning agencies implement people-centered approaches without listening to people that live in risk-prone areas?

\subsection{Challenges of Interdisciplinary Projects}

Warning systems are also a field of power where scientists, civil protection, managers, media, nongovernmental organizations (NGOs), and ordinary people are interlinked. Words, definitions, and languages matter in the interactions between agents with different amounts of capital-economic, political, scientific, and so on (Bourdieu 1991). The recognition that disasters are not natural can imply shifts in power, hierarchies, and management positions, disrupting the status quo and lobbying interests (Hewitt 1983; Kelman 2015).

Initially, I worked in one of the four axes of the warning system. My entry point was the monitoring room, where I worked on shifts for two and a half years. My co-workers were from different disciplines: meteorology, civil engineering, environmental engineering, physics, mathematics, and geography. They used to ask me: "Are you a sociologist? What is a sociologist doing here?" I used to explain that since the 1950s the sociology of disasters is a research area in the United States (Perry 2018), and that before working in the warning agency I had studied temporary shelters in disasters, and that my role in the warning agency was vulnerability analysis. My official job title in the monitoring room was "Natural" Disaster Analyst. At that point, in 2012, I had read Los desastres no son naturales, the publication of La Red (Latin American Social Studies for Disaster Prevention Network) (Maskrey 1993), the book Man and Society in Calamity (Sorokin 1942), and some publications in Spanish that explain why disasters are not natural (Maskrey 1993; Acosta 2005). I read the classic article Taking the "Naturalness" Out of "Natural" Disasters (O'Keefe et al. 1976) during my journey in this scientific laboratory (Latour and Woolgar 1986) where disasters were framed as an agent with rationality, extraordinary or exceptional event (Hewitt 1983).

Disaster analysts were stigmatized because their skills, roles, and responsibilities were not clearly defined in the monitoring teams composed of meteorologists, hydrologists, and geologists. Hazard-centered approaches dominated ordinary conversations as well as the decision making in the monitoring room, especially because the monitoring network provided the kinds of data and maps related to hazards. During this journey in the monitoring room, there was no training highlighting that warning systems should be composed of four elements: risk knowledge, monitoring, communication, and response capability (Basher 2006; Villagrán de León 2012). Nobody mentioned the UNISDR checklist Developing Early Warning Systems (UNISDR 2006a) and its specific recommendations for each of the four subsystems nor its six cross-cutting issues-effective governance, institutional arrangements, multi-hazard approach, involvement of local communities, importance of gender perspectives, and cultural diversity. The Global Survey of Early Warning Systems (UNISDR 2006b) should have been introduced to show the warning levels and criteria adopted for multihazards in different warning agencies around the world. Criteria for warning levels, especially for flash floods, provoked a lot of scientific and technical discussion in our daily activities of the monitoring room. This discussion was related to the number of "false alarms" and our search for criteria to evaluate them.

After two and a half years working on a multidisciplinary team in the monitoring room, where each person used his/her own disciplinary knowledge to analyze data and information, I applied for a researcher position and moved to the risk knowledge subsystem of EWSs. My new boss told me that the academic productivity goal would be two international articles per year and asked me to formulate an interdisciplinary research project-a proposal that integrates knowledge and methods from different disciplines-which would be useful for the monitoring room, not for the warning system. In this new job position, I had new co-workers who specialized in drought analysis, sub-seasonal to seasonal forecasts (S2S), flood and hydraulic modeling, geomorphology, geotechnics, crop failure, forest fire modeling, data analysis, and quantitative vulnerability assessment. With the exception of the vulnerability experts, the other scientists had no previous experience in disaster risk research or warning systems. Each scientist had his/her own technical language. How were we able to establish a dialogue?

Seeking scientific and grey literature about warning systems, I met the Radix (Radical Interpretations of Disaster) Network, whose members suggested some publications to me. Three main topics were essential to establish a dialogue with my co-workers: (1) the amplified version of the disaster risk equation (Wisner et al. 2012) and the interdisciplinary methods of the Forensic Investigations of Disasters-Forin (Oliver-Smith et al. 2016); (2) the discussion of the four axes of warning systems (Basher 2006; Kelman and Glantz 2014) that help us to think about the potential role of each scientist on each axis; and (3) the recommendations of the HFA (UNISDR 2005) and SFDRR (UNISDR 2015) regarding the importance of building people-centered and multi-hazard EWSs.

For the first point, disaster risk (DR) is a function of hazards $(\mathrm{H})$, vulnerability $(\mathrm{V})$, capacity $(\mathrm{C})$, and largerscale risk mitigation $(\mathrm{M})$ by preventive action and social protection, which can be mnemonically represented as: 
$\mathrm{DR}=\mathrm{H} \times[(\mathrm{V} / \mathrm{C})-\mathrm{M}]($ Wisner et al. 2012). Disaster risk is not natural, but arises because social processes create, maintain, increase, and/or reduce a group's and individual's susceptibility to suffer loss, injury, or death; limit or increase people's access to resources-political, economic, social, human, physical, and natural-as well as their ability to anticipate, cope with, and recover from harm (Wisner et al. 2004, 2012; Wisner 2016).

Can this risk equation be applied to the four axes of warning systems-risk knowledge, monitoring, communication, and response capability? During the course of doing interdisciplinary projects at the warning agency, we designed some conceptual frameworks considering the four axes of EWSs, the potential research topics, methods, policies, and responsible agencies (Anderson et al. 2019; Cunha et al. 2019). But sometimes there were competing hazards in the monitoring room routine, one would be prioritized and an equitable multi-hazards approach would be undermined. Hazards have different frequencies and speeds of onset, so they do not carry the same weight in the political agenda. In my case study, it was interesting to see how the climate patterns and political conditions intersected to define the prioritized hazard. The national warning agency was created to monitor flash floods, floods, and landslides. However, an extended drought (2012-2016) drove the warning agency to also monitor droughts and their impacts. This drought monitoring was not delegated to the analysists of the monitoring room, but to new scientists to whom scholarships were awarded.

These shifts and routine problems can undermine the investments and efforts to treat each hazard across the four axes of warning, to increase the risk knowledge across temporal and spatial scales. Risk knowledge can be developed, showing evidence to communicate warnings about the past, the present, and the future. New monitoring tools can be developed to visualize the long-term disaster risk creation in the past and in the future across spatial scales. These initiatives can be useful for several purposes, including the challenge of building people-centered warning systems.

\subsection{People-Centered Early Warning Systems?}

"To save lives" is the message pronounced by warning agencies when they need to show the importance of their mission. Frequently, they need to convince different audiences using recommendations of the HFA and SFDRR regarding the need of building people-centered and multihazard approaches. These two key recommendations do not have the same weight because scientists-depending on their expertise - and other actors attribute different degrees of importance to them, according to their interests. Hierarchies between sciences and scientists are reproduced and influence how the problems are framed. As a sociologist, I used to wonder how it would be possible to try to save lives in disasters without being people-centered. But most of my co-workers used to frame their research problem differently during our interactions. They had no idea what "last mile" and "first mile" approaches meant to warning systems.

The "last mile" approach received this name because people-whose bodies in purely biological terms (Foucault 2007) must be "saved" - are the last to be involved in the warning system. Usually, the efforts and investments are on sensors and monitoring networks managed by regional or national agencies, whereas communication and response capability in the local agencies and communities are the weaker elements (Garcia and Fearnley 2012). People are included as receivers of alerts sent via short message services (SMS), apps, TV, and so on. This top-down approach ignores that societies have a long history of coping with calamities (Hewitt 1983), that people have created their own traditional warning systems (Santha et al. 2014).

Putting people first is the key message of the approach known as "first mile." Criticizing the dominance of the hazard paradigm in the warning system debate, this approach advocates more discussion to understand who the people are, their degrees of vulnerability and capacities, their needs in terms of gender (Mustafa et al. 2015), age (Peek 2008), disability (Bennett 2020), mobility status, language, and culture, spreading the message "leaving no one behind." Some scholars have pointed out that this type of warning system can be tailored for different audiences as well as used for vulnerability reduction (Kelman and Glantz 2014) in different sectors, such as urban planning (Zia and Wagner 2015). This approach takes into account that vulnerabilities are dependent on root causes and dynamic pressures (Wisner et al. 2012) that shape differentiated access to rights and resources-healthcare services, education, access to information-and will contribute to our ability to prepare, cope with, and recover in the aftermath of hazards.

The human and social dimensions in warning systems are exemplified in many terminologies used in the scientific and grey literature: people-centered EWSs (UNISDR 2005), community early warning systems - CEWS (IFRC 2012), citizen-centered EWSs (Mustafa et al. 2015), community-centric EWSs (Baudoin et al. 2016), communitybased EWSs (Macherera and Chimbari 2016a), and participatory EWSs (Marchezini, Trajber, et al. 2017).

At my warning agency nobody talks about communitybased EWSs, CEWSs, or citizen-centered EWSs. The entry point for a "first mile" approach was an educational project. The educational project was also an entry point for interdisciplinary projects because it has engaged scientists from different disciplines in developing tutorials for basic 
scientific initiation in high schools. Defined as the engagement of members of the general public in data collection and analysis, and usually as part of a collaborative project with professional scientists, the concept of citizen science (Bonney et al. 2016) has been useful for involving some scientists in this education project that began in 2014 and works with high schools, communities, and civil protection towards disaster prevention. However, 4 years have passed and the project has not scaled up, despite the attempts to involve the Ministry of Education and the National Civil Defense. When referring to a people-centered approach, it is essential to remember that scientists, politicians, policymakers, and civil protection agents are part of it. These groups can be considered part of the solution and/or included as components of institutional vulnerability.

Moving from this local and national experience analyzed from 2012 to 2018, the second part of this article discusses some global social challenges of warning systems. First, some challenges of the people-centered approach are highlighted. Then, the multi-hazard approach is considered.

\section{Discussion: Challenges of People-Centered and Multi-hazard Approaches}

Scientific and grey literature in Spanish and in English provides important inputs for warning system implementation in SFDRR. This section considers two main issues: (1) experiences of implementation and barriers related to people-centered warning systems; and (2) types of national/regional warning systems and hazards/threats that are being monitored as an important input for multi-hazard approaches.

\subsection{Participatory Early Warning Systems: Inputs for the Sendai Framework for Disaster Risk Reduction}

Macherera and Chimbari (2016a) explained how terminologies often emphasize the need of community participation in EWS development, but they do not qualify the extent of engagement or types of participation. Participation has different meanings. It can range from coercion (passive participation, where the will of one group is effectively imposed on another group) to co-acting (active participation where participants set their own agendas) (Dyball et al. 2009). These different kinds of participation might be useful in rethinking whether and how different audiences should be part of people-centered approaches.

Participation in warning systems is a challenge for a number of reasons. Despite the growing number of scientific articles about warning systems published in English from 2005 to June 2018 (Marchezini et al. 2018), the scientific contribution to identifying "how to build people-centered systems" is highly concentrated in a "research-prone" area-Asian countries (56\%)—where scientists affiliated with organizations from developed regions-mainly the United States, Europe, Japan, and Australia-went to develop their studies. The second reason is the disproportionate number of certain hazards addressed in participatory initiatives that reveal the inequalities of the multi-hazard approach. Floods represented the most frequent hazard in these selected studies (29\%), followed by tsunamis (13\%) and droughts $(9 \%)$ (Marchezini et al. 2018). The third reason is the perspective of the participation adopted. Marchezini et al. (2018) stated that of the 93 studies selected, almost $85 \%$ reported participatory experiences in a consultative way, that is, through surveys and interviews. The findings indicated that only $15 \%$ of the selected studies dealt with participatory methodologies that involved data collection and analysis.

There are more important reasons that challenge peoplecentered warning systems. Social contexts where citizenship and participation exist and can be guaranteed are very diverse, unstable, and complex. The possibilities of participation, when they exist, are not equally distributed between the different social groups, and the "windows of opportunity" - to use a fashionable term in the DRR field - are neither open to everybody nor in each of the four axes of the warning systems. The root causes and dynamic pressures help to define the access to resources and their consequent capacities and capabilities-the opportunities and possibilities to execute the capacity/ability.

The imbalance between the four components of warning systems and the emphasis placed on their cross-cutting issues (effective governance, participation, cultural and gender diversity, and so on) are aspects that need to be considered. In Colombia, a national assessment revealed that only in two cases the four axes of warning systems were in place (Domínguez-Calle and Lozano-Báez 2014). Macherera and Chimbari (2016a) also pointed out several gaps, such as the lack of specification of the institutional source of the warning and misunderstanding of how early a warning should be issued. Dávila (2016) pointed out that people are not being involved in the evaluation and improvement of warning messages to take into account their needs in terms of age, ethnicity, disabilities, cultural and gender aspects, as well as their lack of access to resources, such as to technology. The response capability topic - the fourth element of EWSs - was the least found in 21 flood warning initiatives in South and Central America, in comparison to the other three axes of warning systems; community-based frameworks exist only in $20 \%$ of the 21 flood warning initiatives analyzed (Dávila 2016). 
The social perception of the importance of participation across the four axes of warning systems is not homogeneous. In central Italy, the local residents of Lake Trasimeno have not considered themselves as potential sources of knowledge to develop a community-based strategy to monitoring droughts (Giordano et al. 2013). In Cambodia, $86 \%$ of the community members of Svay Rieng Province believed that they personally had no role to play in the dissemination of early warnings for droughts (Nguyen et al. 2009). Frequently, participation is not a matter of choice. Access to resources to engage in warning systems can also be differentiated by gender, sexual and gender minorities, age, race, ethnicity, inhabitants of rural/urban/island/forest areas, people with disabilities, mobility status (refugees, homelessness), or by the combination/intersection of these and other socially defined drivers.

There are people who do not identify with the heterosexual norm and/or the man/woman binary (Gaillard et al. 2017), and this can influence different phases of DRM, including the warning system. In India, the Aravanis faced serious gender discrimination before and after the 2004 tsunami (Pincha and Krishna 2008). This sexual and gender minority cannot be classified and explained using a twogender category and the systemic rejection suffered has pushed them into extreme poverty. The tsunami fatalities among the Aravanis were not recorded in the official statistics of the 2004 catastrophe, their family members received no government compensation, and they still lack access to safe housing, citizenship documents, secure livelihoods, disaster preparedness, and capacity building, among others (Pincha and Krishna 2008).

Children and youth are other social groups that historically have been neglected because they are not in policymaking or relevant professional positions to push their needs forward (Anderson 2005; Peek 2008). In Zimbabwe, despite some progress in promoting disaster education for some children that are in schools, children were not aware of any disaster management plan in the community, and their level of preparedness was low, which indicated a need for community-centered early warning systems (MuzendaMudavanhu et al. 2016). In Brazil, despite developing participatory methodologies to engage high schools in the four elements of EWSs with the help of school curricula, the challenge is to scale up pilot projects to other schools that are located in flood- and landslide-prone areas (Marchezini, Trajber, et al. 2017). The problem overall is not the lack of knowledge and/or recommendations. Over the last dozen years, several studies have recommended pathways for enhancing youth participation (Peek 2008; Fernandez and Shaw 2013), including the UNESCO initiative to analyze DRR in school curricula in 30 countries (Selby and Kagawa 2012). But the implementation of these recommendations is still a challenge (Cumiskey et al. 2015).

Human mobility can be another important driver of vulnerability because it can imply the loss of territorythat is deterritorialization. Guadagno (2016) stated that the Sendai Framework should include migrants in DRM and EWSs, providing appropriate structures and procedures, as well as collecting data disaggregated by mobility status and other characteristics (gender, age, ethnicity, and so on). Warning systems have faced this type of challenge. In the United States, 11.2 million undocumented migrants need to be included in the tornado warning system (Stokoe 2016).

The intersection of vulnerabilities, hazards, and threats—including conflict—demands articulated warning systems that are coordinated structures that go beyond response activities, and integrate science and the notion of long-term communication for the implementation of actions to achieve efficient DRM (Alcántara-Ayala and Oliver-Smith 2017). One important step is to identify the existing warning systems that can be articulated.

\subsection{Multi-hazard Approaches: Inputs for the Sendai Framework for Disaster Risk Reduction}

Despite the losses and damages suffered during droughts, few drought EWSs exist worldwide according to the review conducted by Grasso (2014). Although this review included Colombia in the list of countries without a drought EWS, Domínguez-Calle and Lozano-Báez (2014) reported a participatory agro-climatic warning system in the Cauca watershed where traditional knowledge of indigenous peoples and campesinos (small farmers) is combined with scientific knowledge. In this mixed system, the weather forecast is obtained from the National Oceanic and Atmospheric Administration (NOAA) and the Institute of Hydrology, Meteorology and Environmental Studies (IDEAM), and the traditional knowledge of indigenous people and campesinos is used to identify biological indicators and thresholds at the community level (DomínguezCalle and Lozano-Báez 2014).

Traditional flood warning systems existed before modern monitoring systems. In Latin America, there are some cases of warning systems that take into account indigenous knowledge, tailoring EWSs according to the cultural, gender, and social needs (Lópes-García et al. 2017). In Peru, the watersheds of the Piura and Inambari Rivers are monitored by campesinos (Dávila 2016). In Nicaragua, the communities of the subbasins of the Esteli and Coco Rivers monitor hand-made rain and river level gauges and use radio to communicate the data to the emergency management centers (Dávila 2016). Around the world, there are many examples of traditional and community-based warning systems for volcanoes (Donovan et al. 2012; Stone 
Table 1 Hazards, number of warning frameworks, and coverage

\begin{tabular}{|c|c|c|}
\hline Hazard & $\begin{array}{l}\text { Number of EWS } \\
\text { frameworks }\end{array}$ & Coverage \\
\hline $\begin{array}{l}\text { General } \\
\text { weather }\end{array}$ & 21 & $\begin{array}{l}\text { Canada, Colombia, England, Netherlands, Belgium, Germany, Austria, Switzerland, France, Spain, } \\
\text { Portugal, Romania, Antilles-Guyane, New Caledonia, Japan, Malaysia, Australia, New Zealand, } \\
\text { Europe-Meteoalarm ( } 25 \text { European countries), the mainland of China, Taiwan (Villagrán de León et al. } \\
\text { 2013) }\end{array}$ \\
\hline $\begin{array}{l}\text { Tropical } \\
\text { cyclone }\end{array}$ & 23 & $\begin{array}{l}\text { Bahamas, Cuba, Jamaica, St.Vincent and the Grenadines, Grenada, Netherlands Antilles and Aruba, } \\
\text { Cayman Islands, USA, Canada, Mexico, Mozambique, Mauritius, La Reunion (France), India, } \\
\text { Bangladesh, Hong Kong, Taiwan, Philippines, Australia, French Polynesia, New Caledonia, Macau, } \\
\text { Fiji (South Pacific Area) (Villagrán de León et al. 2013) }\end{array}$ \\
\hline \multirow[t]{3}{*}{ Flood } & \multirow[t]{3}{*}{39} & $\begin{array}{l}\text { USA, Canada (Ontario), Canada (Alberta), Canada (British Columbia), Jamaica, Colombia, England, } \\
\text { Scotland, Norway, Belgium, Germany, Czech Republic, France, the mainland of China, India, } \\
\text { Bangladesh, Hong Kong, Japan, Philippines, Malaysia, Australia, Vietnam, Laos, Pakistan (Villagrán } \\
\text { de León et al. 2013) }\end{array}$ \\
\hline & & $\begin{array}{l}\text { Guatemala, Honduras, El Salvador, Nicaragua, Zimbabwe, South Africa; inadequate coverage of flood } \\
\text { warning systems in Brazil, Nepal, Bangladesh, India, China (Grasso 2014) }\end{array}$ \\
\hline & & Argentina, Bolivia, Brazil, Colombia, El Salvador, Guatemala, Nicaragua, Peru, Venezuela (Dávila 2016) \\
\hline Drought & 9 & $\begin{array}{l}\text { USA (2), Famine Early Warning Systems Network - FEWS (Central America, East and West Africa, } \\
\text { Central Asia), Central America, Africa (West, East, South), Kenya, Kenya (community-based early } \\
\text { warning systems), East Africa, Global (Food and Agriculture Organization of the United Nations - } \\
\text { FAO) (Villagrán de León et al. 2013); Lack of warning systems in western, southern, and eastern } \\
\text { Africa; in Europe (Spain, parts of France, southern Sweden, and northern Poland); in Asia (India, parts } \\
\text { of Thailand, Turkey, Iran, Iraq, eastern China); in Latin America (areas of Ecuador, Colombia); and in } \\
\text { the southeastern and western parts of Australia (Grasso 2014) }\end{array}$ \\
\hline Heat wave & 9 & $\begin{array}{l}\text { USA, Canada (Toronto), Canada (Kingston), Switzerland, Germany, England, Italy, Europe } \\
\text { (Meteoalarm), Hong Kong (Villagrán de León et al. 2013) }\end{array}$ \\
\hline Storm surge & 11 & $\begin{array}{l}\text { Canada (2), Finland (3), Japan, New Zealand, Australia, Italy, USA, Hong Kong (Villagrán de León et al. } \\
\text { 2013) }\end{array}$ \\
\hline \multirow[t]{3}{*}{$\begin{array}{l}\text { Volcanic } \\
\text { activity }\end{array}$} & \multirow[t]{3}{*}{16} & $\begin{array}{l}\text { USA, El Salvador, Guatemala, Montserrat, Mexico, Colombia, Nicaragua, Italy, La Reunion (France), } \\
\text { Japan, Philippines, Indonesia, New Zealand, Global (The United States Geological Survey - USGS) } \\
\text { (Villagrán de León et al. 2013) }\end{array}$ \\
\hline & & Congo and Cameroon have volcano monitoring observatories (Grasso 2014) \\
\hline & & Fewer than 50 of the world's volcanoes are being monitored (Grasso 2014) \\
\hline \multirow[t]{2}{*}{ Earthquake } & \multirow[t]{2}{*}{8} & Mexico, Japan, Taiwan, Canada, Italy, Greece, USA, Nicaragua (Villagrán de León et al. 2013) \\
\hline & & $\begin{array}{l}\text { Many high seismic risk countries still lack such systems (that is, Peru, Chile, Iran, Pakistan, India) } \\
\text { (Grasso 2014) }\end{array}$ \\
\hline Tsunami & 13 & $\begin{array}{l}\text { Pacific Ocean, Indian Ocean, Caribbean, NEAMS (North Eastern Atlantic, Mediterranean and Connected } \\
\text { Seas); USA, Canada (West Coast and Alaska), Chile, Nicaragua, Seychelles, Hong Kong, Japan, } \\
\text { Australia, Indonesia (Villagrán de León et al. 2013) }\end{array}$ \\
\hline \multirow[t]{2}{*}{ Landslide } & \multirow[t]{2}{*}{11} & USA, Hong Kong, Japan (Villagrán de León et al. 2013) \\
\hline & & Canada, Czech Republic, France, China, Italy, Norway, Slovakia, Spain (Michoud et al. 2013) \\
\hline Avalanche & 4 & USA, Canada, New Zealand, Europe (Villagrán de León et al. 2013) \\
\hline Forest fire & 16 & $\begin{array}{l}\text { USA (2), Canada, Cuba, Brazil, Argentina, Sweden, Finland, Germany, Poland, Italy, Europe (Joint } \\
\text { Research Center), Korea, Malaysia, Australia, New Zealand (Villagrán de León et al. 2013) }\end{array}$ \\
\hline Influenza & - & World Health Organization (Villagrán de León et al. 2013) \\
\hline Air quality & 13 & $\begin{array}{l}\text { Air quality monitoring systems exist for many countries worldwide, but appear to be most developed in } \\
\text { the United States, Canada, and Europe. Additional successful systems are operational in Asia (Taiwan, } \\
\text { the mainland of China, Hong Kong, Korea, Japan, Thailand), in Latin America (Argentina, Brazil, } \\
\text { Mexico City), and in Africa (Cape Town in South Africa) (Grasso 2014) }\end{array}$ \\
\hline $\begin{array}{l}\text { Multi- } \\
\text { hazards }\end{array}$ & 8 & $\begin{array}{l}\text { Peru, El Salvador, Guatemala, Honduras, Sweden, Denmark, Austria, China (Villagrán de León et al. } \\
\text { 2013) }\end{array}$ \\
\hline
\end{tabular}

Source Compiled by the author based on data and information from Villagrán de León (2013, p. 80), Michoud et al. (2013), Grasso (2014), and Dávila (2016) 
et al. 2014), droughts (Chisadza et al. 2013), tsunamis (Gaillard et al. 2008), and malaria (Macherera and Chimbari 2016b). There are also surveys that identified regional and/or national warning systems for different hazards (Table 1). The warning frameworks identified were mostly related to hydrometeorological hazards (112), while 52 were related to geological hazards, followed by forest fires (16) and air quality (13) (Table 1).

Another important source for data and information about hazards and threats is the Global Network of Civil Society Organizations for Disaster Reduction (GNDR). This network carried out independent assessments to look at the priority actions from the grassroots, which should be the most important inputs for people-centered and multi-hazard warning systems. The Views from the Frontline (VFL) editions were published in 2009, 2011, 2013 (Gibson and Wisner 2016), and in 2019 (GNDR 2019). The VFL data can be important to plan warning systems that also address hazards and threats identified by people. Depending on the hazards and threats, different spatial and temporal scales can be selected and those choices will imply that the people-centered approach will engage different actors, not only people potentially exposed, as well as those agents, companies, and governments directly and indirectly responsible for disaster risk creation and DRM; for example, dam companies, the mining sector, and nuclear plants need to be urgently monitored. Banks, private companies, civil society organizations, and national, regional, and local governments should be involved in strategies to reduce disaster risk creation processes.

\section{Implications for the Sendai Framework for Disaster Risk Reduction}

The Sendai Framework has achieved results regarding the need for building warning systems for natural hazardsmainly hydrometeorological types-as well as for spreading the message of designing frameworks considering the four subsystems. The last mile and first mile approaches are also being discussed, but people-centered experiences of implementation are still lacking. There is increased recognition of the main barriers in the warning system agenda:

- hazard-centered approaches;

- lack of funding;

- lack of, and/or deterioration of, monitoring networks;

- lack of human resources, and high rates of employee turnover;

- lack of consensus in warning terminology (criteria for the levels of alerts and their consequent false alarms, and so on);
- lack of specification of the institutional sources of the alerts;

- lack of warning systems for landslides, and insufficient coverage of warnings for some types of natural hazards in some regions;

- political influence;

- competing interests within and between academic fields, the private sector, and the public sector;

- inadequate coordination within and between the local, regional, national, and international levels;

- lack of data governance, and disaggregated data;

- lack of interdisciplinary and transdisciplinary methods to increase the extent of engagement and the types of participation of different audiences in the four axes of warning systems;

- lack of strategies to involve people in evaluation and improvement of warning systems;

- and the short period of research projects and the lack of time for implementation.

The Sendai Framework neglects some important topics and needs to especially look at:

(1) Political threats: displacement, conflicts, and protracted crises (FAO 2010); lack of budget for poverty alleviation and vulnerability reduction programs, especially in some regions of Africa and Asia where the number of undernourished people has risen to almost 100 million since 2005 (FAO et al. 2019); the old and new forms of discrimination against refugees, homelessness (Guadagno 2016), and minorities; the increase of totalitarian regimes and the use of the state of exception (Agamben 2005); climate change denial (Dunlap and McCright 2015) and the political controversy against scientific data; and,

(2) strategies to articulate and amplify the hazards/ threats and vulnerabilities monitored and, consequently, the access to data and information, including new everyday disasters such as air pollution that is responsible for more than four million deaths each year ( $\mathrm{Li}$ et al. 2019); water quality; old and new diseases; nuclear plant, dam, and critical infrastructure safety (communication, energy), as well as their combined potential to generate cascading disasters (Alexander and Pescaroli 2019); the disaster risk creation process at larger scale, such as the 43 dams planned in the Tapajós Basin, Brazilian Amazon (Fearnside 2015).

More than ever, the Sendai Framework needs to take into account the social and political aspects. It is essential to promote the use of the amplified version of the disaster risk equation (Wisner et al. 2012) to point out the importance of public policies of mitigation in the articulated warning systems (Alcántara-Ayala and Oliver-Smith 2017). To formulate proposals aligned with this scope, it is necessary to: (1) identify and connect different types of 
national/regional warning systems (Table 1), including those promoted by UN agencies; (2) tailor warning systems for different sectors, such as urban planning (Zia and Wagner 2015) and education (Marchezini, Trajber, et al. 2017); and (3) engage different audiences in warning systems.

Acknowledgements The author acknowledges the São Paulo Research Foundation - Fapesp (Grant Number 2018/06093-4).

Open Access This article is licensed under a Creative Commons Attribution 4.0 International License, which permits use, sharing, adaptation, distribution and reproduction in any medium or format, as long as you give appropriate credit to the original author(s) and the source, provide a link to the Creative Commons licence, and indicate if changes were made. The images or other third party material in this article are included in the article's Creative Commons licence, unless indicated otherwise in a credit line to the material. If material is not included in the article's Creative Commons licence and your intended use is not permitted by statutory regulation or exceeds the permitted use, you will need to obtain permission directly from the copyright holder. To view a copy of this licence, visit http://creativecommons. org/licenses/by/4.0/.

\section{References}

Acosta, V.G. 2005. Risk as social construction and the social production of risk (El riesgo como construcción social y la construcción social de riesgos). Desacatos- Revista de Antropologia Social 19: 11-24 (in Spanish).

Agamben, G. 2005. State of exception. Chicago: University of Chicago Press.

Alcántara-Ayala, I., and A. Oliver-Smith. 2017. The necessity of Early Warning Articulated Systems (EWASs): Critical issues beyond response. In Identifying emerging issues in disaster risk reduction, migration, climate change and sustainable development, ed. K. Sudmeier-Rieux, M. Fernández, I.M. Penna, M. Jaboyedoff, and J.C. Gaillard, 101-124. Springer: London.

Alexander, D., and G. Pescaroli. 2019. What are cascading disasters? UCL Open Environment 1: Article 03.

Anderson, W.A. 2005. Bringing children into focus on the social science disaster research agenda. International Journal of Mass Emergencies and Disasters 23(3): 159-175.

Anderson, L.O., V. Marchezini, T.F. Morello, and C. Cunningham. 2019. Warning system and disaster risk management frameworks for disasters related to forest fires and the challenges for public policies in Brazil (Modelo conceitual de sistema de alerta e de gestão de riscos e desastres associados a incêndios florestais e desafios para políticas públicas no Brasil). Territorium 26(1): 43-61 (in Portuguese).

Basher, R. 2006. Global early warning systems for natural hazards: Systematic and people-centred. Philosophical Transactions. Series A, Mathematical, Physical, and Engineering Sciences 364(1845): 2167-2182.

Baudoin, M.A., S. Henly-Shepard, N. Fernando, A. Sitati, and Z. Zommers. 2016. From top-down to community-centric approaches to early warning systems: Exploring pathways to improve disaster risk reduction through community participation. International Journal of Disaster Risk Science 7(2): 163-174.

Bennett, D. 2020. Five years later: Assessing the implementation of the four priorities of the Sendai framework for inclusion of people with disabilities. International Journal of Disaster Risk Science. https://doi.org/10.1007/s13753-020-00267-w.

Bonney, R., C. Cooper, and H. Ballard. 2016. The theory and practice of citizen science: Launching a new journal. Citizen Science: Theory and Practice 1(1): 1.

Bourdieu, P. 1991. Language and symbolic power. Cambridge: Polity Press.

Chisadza, B., M.J. Tumbare, I. Nhapi, and W.R. Nyabeze. 2013. Useful traditional knowledge indicators for drought forecasting in the Mzingwane Catchment area of Zimbabwe. Disaster Prevention and Management 22(4): 312-325.

Cumiskey, L., T. Hoang, S. Suzuki, C. Pettigrew, and M.M. Herrgard. 2015. Youth participation at the third UN World Conference on Disaster Risk Reduction. International Journal of Disaster Risk Science 6(2): 150-163.

Cunha, A.P.M.A., V. Marchezini, D.P. Lindoso, S.M. Saito, and R.C.S. Alvalá. 2019. The challenges of consolidation of a drought-related disaster risk warning system to Brazil. Sustentabilidade em Debate 10(1): 43-59.

Dávila, D. 2016. Flood warning systems in Latin America (Sistemas de alerta temprana ante inundaciones en América Latina). Lima: Soluciones Prácticas (in Spanish).

Devault, M.L. 2006. Introduction: What is institutional ethnography? Social Problems 53(3): 294-298.

Dombrowsky, W. 1998. Again and again: Is a disaster we call a "disaster"? In What is a disaster? Perspectives on the question, ed. E. Quarantelli, 19-30. London and New York: Routledge.

Domínguez-Calle, E., and S. Lozano-Báez. 2014. A literature review of warning systems in Colombia (Estado del arte de los sistemas de alerta temprana en Colombia). Revista de la Academia Colombiana de Ciencias Exactas, Físicas y Naturales 38(148): 321-333 (in Spanish).

Donovan, K., A. Suryanto, and P. Utami. 2012. Mapping cultural vulnerability in volcanic regions: The practical application of social volcanology at Mt Merapi, Indonesia. Environmental Hazards 11(4): 303-323.

Dunlap, R.E., and A.M. McCright. 2015. Challenging climate change: The denial countermovement. In Climate change and society: Sociological perspectives, ed. R.E. Dunlap, and R.J. Brulle, 300-332. New York: Oxford University Press.

Dyball, R., V.A. Brown, and M. Keen. 2009. Towards sustainability: Five strands of social learning. In Social learning towards a sustainable world: Principles, perspectives, and praxis, ed. A.E.J Wals, 181-194. Netherlands: Wageningen Academic Publishers.

FAO (Food and Agriculture Organization of the United Nations). 2010. Countries in protracted crisis: What are they and why do they deserve special attention? Rome, Italy: FAO. https://www. fao.org/3/i1683e/i1683e03.pdf. Accessed 18 Dec 2019.

FAO, IFAD, UNICEF, WFP and WHO (Food and Agriculture Organization of the United Nations, et al.). 2019. The state of food security and nutrition in the world 2019: Safeguarding against economic slowdowns and downturns. Rome: FAO.

Fearnside, P.M. 2015. Amazon dams and waterways: Brazil's Tapajós Basin plans. Ambio 44(5): 426-439.

Fernandez, G., and R. Shaw. 2013. Youth council participation in disaster risk reduction in the Philippines. International Journal of Disaster Risk Science 4(3): 126-136.

Foucault, M. 2007. Security, territory, population: Lectures at the Collège de France, 1977-1978. New York: Palgrave Macmillan.

Gaillard, J.C., E. Clave, O. Vibert, D. Azhari, J.C. Denain, Y. Efendi, D. Grancher, C.C. Liamzon, D.S.R. Sari, and Setiawan, R. 2008. Ethnic groups' response to the 26 December 2004 earthquake and tsunami in Aceh, Indonesia. Natural Hazards 47(1): 17-38. 
Gaillard, J.C., A. Gorman-Murray, and M. Fordham. 2017. Sexual and gender minorities in disaster. Gender, Place \& Culture 24(1): 18-26.

Garcia, C., and C.J. Fearnley. 2012. Evaluating critical links in early warning systems for natural hazards. Environmental Hazards 11(2): 123-137.

Gibson, T., and B. Wisner. 2016. "Let's talk about you...": Opening space for local experience, action and learning in disaster risk reduction. Disaster Prevention and Management 25(5): 664-684.

Giordano, R., E. Preziosi, and E. Romano. 2013. Integration of local and scientific knowledge to support drought impact monitoring: Some hints from an Italian case study. Natural Hazards 69(1): 523-544.

GNDR (Global Network of Civil Society Organizations for Disaster Reduction). 2019. Views from the frontline 2019. https://www. gndr.org/programmes/views-from-the-frontline/vfl-2019.html. Accessed 5 Nov 2019.

Grasso, V.F. 2014. The state of early warning systems. In Reducing disaster: Early warning systems for climate change, ed. Z. Zommers, and A. Singh, 109-126. Dordrecht: Springer.

Guadagno, L. 2016. Human mobility in the Sendai framework for disaster risk reduction. International Journal of Disaster Risk Science 7(1): 30-40.

Hewitt, K. 1983. The idea of calamity in a technocratic age. In Interpretations of calamity, ed. K. Hewitt, 3-32. Boston: Allen and Unwin.

Horita, F.E.A, J.P. Albuquerque, and V. Marchezini. 2018. Understanding the decision-making process in disaster risk monitoring and early-warning: A case study within a control room in Brazil. International Journal of Disaster Risk Reduction 28: 22-31.

Horita, F.E.A, J.P. Albuquerque, V. Marchezini, and E.M. Mendiondo. 2017. Bridging the gap between decision-making and emerging big data sources: An application of a model-based framework to disaster management in Brazil. Decision Support Systems 97: 12-22.

IFRC (International Federation of the Red Cross and Red Crescent Societies). 2012. Community early warning systems: Guiding principles. Geneva, Switzerland: IFRC.

Kelman, I. 2006. Warning for the 26 December 2004 Tsunamis. Disaster Prevention and Management 15(1): 178-189.

Kelman, I. 2015. Climate change and the Sendai framework for disaster risk reduction. International Journal of Disaster Risk Science 6(2): 117-127.

Kelman, I., and M.H. Glantz. 2014. Early warning systems defined. In Reducing disaster: Early warning systems for climate change, ed. Z. Zommers, and A. Singh, 89-108. Dordrecht: Springer.

Klein, N. 2008. The shock doctrine: The rise of disaster capitalism. New York: Picador.

Latour, B., and S. Woolgar. 1986. Laboratory life: The construction of scientific facts. New Jersey: Princeton University Press.

Li, X., L. Jin, and H. Kan. 2019. Air pollution: A global problem needs local fixes. Nature 570(7762): 437-439.

López-García, J.D., Y. Carvajal-Escobar, and A.M. Enciso-Arango. 2017. Early warning systems with a participatory approach: Challenges for disaster risk management in Colombia (Sistemas de alerta temprana con enfoque participativo: Un desafio para la gestión del riesgo en Colombia). Revista Luna Azul 44: 231-246 (in Spanish).

Lumbroso, D., E. Brown, and N. Ranger. 2016. Stakeholders' perceptions of the overall effectiveness of early warning systems and risk assessments for weather-related hazards in Africa, the Caribbean and South Asia. Natural Hazards 84(3): 2121-2144.

Lund, C. 2006. Twilight institutions: Public authority and local politics in Africa. Development and Change 37(4): 685-705.
Macherera, M., and M.J. Chimbari. 2016a. A review of studies on community based early warning systems. Jàmbá: Journal of Disaster Risk Studies. https://doi.org/10.4102/jamba.v8i1.206.

Macherera, M., and M.J. Chimbari. 2016b. Developing a communitycentred malaria early warning system based on indigenous knowledge: Gwanda District, Zimbabwe. Jàmbá: Journal of Disaster Risk Studies. https://doi.org/10.4102/jamba.v8i1.289.

Maly, E., and A. Suppasri. 2020. The Sendai framework for disaster risk reduction at five: Lessons from the 2011 great East Japan earthquake and tsunami. International Journal of Disaster Risk Science. https://doi.org/10.1007/s13753-020-00268-9.

Marchezini, V., F.E.A. Horita, P.M. Matsuo, R. Trajber, M.A. TrejoRangel, and D. Olivato. 2018. A review of studies on Participatory Early Warning Systems (P-EWS): Pathways to support citizen science initiatives. Frontiers in Earth Science 6: Article 184.

Marchezini, V., L. Londe, T. Bernardes, R.S. Conceição, E.V. Santos, S.M. Saito, L. Soler, A.E.P. Silva, et al. 2017. Sistema de alerta de risco de desastres no Brasil: Desafios à redução da vulnerabilidade institucional. In Reduction of vulnerability to disasters: from knowledge to action, ed. V. Marchezini, B. Wisner, L.R. Londe and S.M. Saito, 287-310. São Carlos: Rima Editora.

Marchezini, V., R. Trajber, D. Olivato, V. Muñoz, F. Oliveira Pereira, and A.E. Oliveira Luz. 2017. Participatory early warning systems: Youth, citizen science, and intergenerational dialogues on disaster risk reduction in Brazil. International Journal of Disaster Risk Science 8(4): 390-401.

Maskrey, A. 1993. Disasters are not natural (Los desastres no son naturales). Panamá City: La Red (in Spanish). https://www. desenredando.org/public/libros/1993/ldnsn/LosDesastresNoSon Naturales-1.0.0.pdf. Accessed 13 Oct 2019.

Michoud, C., S. Bazin, L.H. Blikra, M.H. Derron, and M. Jaboyedoff. 2013. Experiences from site-specific landslide early warning systems. Natural Hazards and Earth System Sciences 13(10): 2659-2673.

Mustafa, D., G. Gioli, S. Qazi, R. Waraich, A. Rehman, and R. Zahoor. 2015. Gendering flood early warning systems: The case of Pakistan. Environmental Hazards 14(4): 312-328.

Muzenda-Mudavanhu, C., B. Manyena, and A.E. Collins. 2016. Disaster risk reduction knowledge among children in Muzarabani District, Zimbabwe. Natural Hazards 84(2): 911-931.

Nguyen, H., S.V.R.K. Prabhakar, and R. Shaw. 2009. Adaptive drought risk reduction in Cambodia: Reality, perceptions and strategies. Environmental Hazards 8(4): 245-262.

Norambuena, R.C. 2011. A survey of tsunami warning systems in the Southeast Pacific (Diagnóstico de los Sistemas de Alerta Temprana ante Tsunami en el Pacífico Sudeste). Santiago: DIPECHO (in Spanish).

O'Keefe, P., K. Westgate, and B. Wisner. 1976. Taking the naturalness out of natural disasters. Nature 260: 566-567.

Oliver-Smith, A., I. Alcántara-Ayala, I. Burton, and A. Lavell. 2016. Forensic Investigations of Disasters (FORIN): A conceptual framework and guide to research (2016). IRDR FORIN Publication No.2. Beijing: Integrated Research on Disaster Risk. https://www.irdrinternational.org/wp-content/uploads/2016/01/ FORIN-2-29022016.pdf. Accessed 9 Jul 2019.

Peek, L. 2008. Children and disasters: Understanding vulnerability, developing capacities, and promoting resilience - An introduction. Children, Youth and Environments 18(1): 1-29.

Perry, R.W. 2018. Defining disaster: An evolving concept. In Handbook of disaster research, ed. H. Rodriguez, W. Dooner, and J.E. Trainor, 3-22. Cham, Switzerland: Springer.

Pincha, C., and H. Krishna. 2008. Aravanis: Voiceless victims of the Tsunami. Humanitarian Exchange 41: 41-43. 
Saito, S.M., G.R.T. Lima, and M.C.A. Dias. 2019. Evaluation by the end-users of disaster risk warnings in Brazil. Sustentabilidade em Debate 10(2): 38-53.

Santha, S., P. Gahana, and V.S. Aswin. 2014. Local knowledge, early warning and coastal hazards: Participatory inquiry among fishworkers in Kerala, India. Action Research 12(3): 273-292.

Selby, D., and F. Kagawa. 2012. Disaster risk reduction in school curricula: Case studies from thirty countries. Paris: UNESCO and UNICEF.

Sorensen, J.H. 2000. Hazard warning systems: Review of 20 years of progress. Natural Hazards Review 1(2): 119-125.

Sorokin, P. 1942. Man and society in calamity: The effects of war, revolution, famine, pestilence upon human mind, behavior, social organization and cultural life. New York: E.P. Dutton and Company.

Stokoe, R.M. 2016. Putting people at the centre of tornado warnings: How perception analysis can cut fatalities. International Journal of Disaster Risk Reduction 17: 137-153.

Stone, J., J. Barclay, P. Simmons, P.D. Cole, S.C. Loughlin, P. Ramón, and P. Mothes. 2014. Risk reduction through community-based monitoring: The vigías of Tungurahua, Ecuador. Journal of Applied Volcanology 3(1): Article 11.

Thomalla, F., and R.K. Larsen. 2010. Resilience in the context of tsunami early warning systems and community disaster preparedness in the Indian Ocean Region. Environmental Hazards 9(3): 249-265.

UNISDR (United Nations International Strategy for Disaster Reduction). 2005. Hyogo framework for action 2005-2015: Building the resilience of nations and communities to disasters. Geneva: UNISDR.

UNISDR (United Nations International Strategy for Disaster Reduction). 2006a. Developing early warning systems: A checklist. Bonn: UNISDR.

UNISDR (United Nations International Strategy for Disaster Reduction). 2006b. Global survey of early warning systems: An assessment of capacities, gaps and opportunities towards building a comprehensive global early warning system for all natural hazards. Geneva: UNISDR.

UNISDR (United Nations International Strategy for Disaster Reduction). 2015. Sendai framework for disaster risk reduction 2015-2030. Geneva: UNISDR.

UNISDR (United Nations International Strategy for Disaster Reduction). 2017. Terminology: Basic terms of disaster risk reduction. https://www.unisdr.org/we/inform/terminology\#letter-e. Accessed 1 Aug 2019.

Villagrán de León, J.C. 2012. Early warning principles and practices. In Handbook of hazards and disaster risk reduction and management, ed. B. Wisner, J.C. Gaillard, and I. Kelman, 481-492. Oxfordshire: Routledge.

Villagrán de León, J.C., I. Pruessner, and H. Breedlove. 2013. Alert and warning frameworks in the context of early warning systems: A comparative review. Bonn: United Nations University.

Wisner, B. 2016. Vulnerability as concept, model, metric, and tool. Oxford Research Encyclopedia of Natural Hazard Science. https://naturalhazardscience.oxfordre.com/view/10.1093/acre fore/9780199389407.001.0001/acrefore-9780199389407-e-25. Accessed 5 Apr 2017.

Wisner, B., P. Blaikie, T. Cannon, and I. Davis. 2004. At risk: Natural hazards, people's vulnerability and disasters. London: Routledge.

Wisner, B., J.C. Gaillard, and I. Kelman. 2012. Framing disaster: Theories and stories seeking to understand hazards, vulnerability and risk. In The Routledge handbook of hazards and disaster risk reduction, ed. B. Wisner, J.C. Gaillard, and I. Kelman, 18-34. London: Routledge.

WMO (World Meteorological Organization). 2018. Multi-hazard early warning system: A checklist. https://library.wmo.int/doc num.php?explnum_id=4463. Accessed 1 Dec 2019.

Zia, A., and C.H. Wagner. 2015. Mainstreaming early warning systems in development and planning processes: Multilevel implementation of Sendai framework in Indus and Sahel. International Journal of Disaster Risk Science 6(2): 189-199. 